\title{
Buddhism and the Challenges of the 21st Century
}

\author{
Donald K. Swearer(Harvard Univ.)
}

I wish thank the President of the Chogye Sangha University, the Venerable Taewon Sunim, and Professor Misan Sunim for this invitation to speak to you today on the topic, "Buddhism and the Challenges of the 21st Century." The question of how Buddhist institutions can and should engage the compelling social, economic, political, and cultural issues of the 21st century is a challenge faced by all of the world religions. Included among the challenges of global significance are poverty and a more equitable distribution of natural resources and wealth; just global health care systems and treatment of pandemic diseases; terrorism and the threat of weapons of mass destruction; technological challenges to what it means to be human; consumerism and an economy of greed; and environmental sustainability.

I want to speak about the last two, consumerism and the environment, with a brief concluding comment about technology. My comments grow out of a long-standing interest in Buddhist social ethics informed by my research primarily in the Theravāda-Southeast Asia context, especially 
Thailand. I am a member of the advisory board of the International Network of Engaged Buddhists(INEB) headquartered in Bangkok; have worked closely with Sulak Sivaraksa, one of the co-founders of INEB; and consider the outstanding Thai monk, Buddhadāsa Bhikkhu, a spiritual mentor. It is this background that informs my remarks.

The world's religions must work collaboratively and not competitively to address these and other 21 st century challenges. Solutions to these challenges depend not only on politicians, economists, scientists, policy makers, and technical experts, but on those who bring shared spiritual and ethical perspectives to bear on an understanding of the human condition and the achievement of an ecology of human flourishing. Joint cooperation in the realization of a shared, common good must take precedence over the pursuit of mere self-interest no matter how well-intended it may be.

\section{Greed, Consumption, and Buddhist Economics}

The current global economic crisis has provoked a broad discussion in the United States and other countries that extends far beyond debates about payments, supports, subsidies, debt, and stimulus packages. Social critics excoriate corporate greed, demand vigilant regulation, castigate the excesses underlying the crisis, and call for a transformation of a 'more is better' consumerist lifestyle. Today, after decades of unprecedented growth, we've learned the lesson that more is not necessarily better; that the very attempt to expand economies may be catastrophically dangerous, and, indeed, that even when growth does make us wealthier that great wealth no longer makes us happy. This insight is, of course, not new. Classic religious and philosophical traditions throughout the world praise 
moderation and critique unbridled consumption. From its very beginning, Buddhism has espoused a Middle Way(maj)hima patipatā) between ascetic denial and indulgent affluence.

From a Buddhist perspective a fundamental question is whether an economic system is conducive to ethical and spiritual development: does it encourage the virtues of generosity, loving-kindness, and wisdom rather than institutionalizing the "three poisons" (greed, ill will, and delusion)? Buddhism neither encourages poverty nor denigrates wealth. Rather, the Buddha's Middle Way focuses on understanding and insight conducive to liberation from our usual preoccupation with satisfying our cravings. In the view of the Thai monk, Buddhadāsa Bhikkhu, whose writings have been a major influence on socially engaged Buddhism in Thailand, Buddhism's middle way reflects the natural order of things, one of balanced distribution and sustainability based on need rather than want:

Nature would have each of us use no more than we actually need. For years people have failed to heed the way of nature, competing with one another to take as much as they can, causing the problems that we live with to this day. If we were to take only what is enough none of these problems would exist. The question is, then, how much is enough. These days it seems that nothing is ever enough. There is a Buddhist saying, 'Even two entire mountains of gold are not enough to satisfy the desires of a single person.' What is needed is an approach that emphasizes not taking more than is needed and that at the same time accords with the laws of nature for then people would share their excess out of loving kindness and compassion. The highest law of nature is to take for ourselves only what is needed, and to accumulate or produce beyond that for the benefit of society. 
For A.T. Ariyaratna, founder of the Sarvodaya Shramadana movement in Sri Lanka, which has conducted development projects in over 11,000 villages on the island, the Buddhist Middle Way translates into what Ariyaratna terms a 'no-poverty society.' Sarvodaya rejects the goal of affluence for everyone on practical grounds. Affluence cannot be achieved by all. The world simply does not have sufficient resources. The social, environmental, moral, and cultural costs of trying to build an affluent society are too great, and exacerbate the gap between the rich and the poor. In the case of Sarvodaya's village development projects, a no-poverty society is defined in terms of meeting ten basic needs: a clean and attractive physical and psychological environment; a clean and adequate supply of water; balanced food requirements; adequate clothing requirements; simple but adequate housing; basic health care; basic communication facilities; minimum energy requirements; comprehensive education; and meeting cultural and spiritual needs. Income and employment are only part of a no-poverty economy. The aim of production in a village economy is not to accumulate profit but, rather to meet the needs of a community, and in doing so to engage all members of the community in that processopportunities for work, education, cooperation for the common good and solving common problems.

A contemporary Buddhist economic ethic critiques consumerism as the commodification of cultural and religious values. Sulak Sivaraksa, the Thai Buddhist social activist and founder of several Buddhist NGO's including the International Network of Engaged Buddhists, characterizes consumerism as the new demonic religion, and Phra Phaisan Visalo a prominent Thai, environmental monk laments: "The distinction between religious faith and consumerism is becoming increasingly vague these 
days. Nowadays, religious faith has been altered to the degree that it means purchasing auspicious objects to worship. One's faith(saddha) is no longer measured by how one applies it, how one lives [one's] life, but by how many holy or sacred articles one possesses."

Although contemporary socially engaged Buddhists attack consumerism as the new global religion, Buddhism's middle way ethic does not reject the accumulation of wealth. It does, however, establish guidelines for its acquisition and use. Wealth honestly gained is praiseworthy but attachment to wealth, even when honestly and lawfully gained, is blameworthy, as is stinginess--not to share one's resources for the benefit and well-being of oneself, one's dependents, and others. Acquiring wealth is acceptable then, if at the same time, it promotes the well being of a community or society.

One of the most praiseworthy moral values is the act of generous giving(dāna) incumbent particularly on people of means. Three basic attitudes toward wealth are central to the value of generous giving. First, dāna reflects the Buddhist critique of craving and hoarding. Buddhism puts the greatest emphasis on cultivating and expressing the attitude of non-attachment. Even a valuable gift given for selfish reasons brings the giver no benefit and may even bring harm; a small gift given selflessly is more praiseworthy. Second, dāna, affirms that the amount of wealth possessed and its distribution is morally secondary compared to the attitude one has toward wealth and the way one uses it. Third, as a moral principle, dāna, affirms the provisional value of wealth as material prosperity. Wealth used in appropriate ways is good, and properly used wealth benefits both the individual and his or her community.

From a Buddhist economic perspective work or labor should be seen 
in the broader framework of right livelihood(samma-ajiva): an opportunity to develop human faculties; to overcome egocenteredness by joining with others in a common task; and to produce goods and services needed for a satisfying life. E. F. Schumacher (Small Is Beautiful: Economics As If People Mattered) critiques modern Western economists who, he contends, consider consumption to be the purpose of economic activity, and tie the maximization of human satisfactions to an optimal pattern of consumption by the optimal pattern of productive effort. From the standpoint of Buddhist economics, however, this understanding of economics is neither rational nor moral. In contrast to an econometric standard that measures wealth by GNP and standard of living by the amount of annual consumption, Buddhist economics views consumption as a means to human well-being. Buddhist economics postulates that the essence of human flourishing is not in the multiplication of wants but in the development of human character or, in the words of the Vietnamese monk, Thich Nhat Hanh, an expression of our deepest self. Work, therefore, should aim to promote character and human dignity.

\section{Buddhism, Ecology, and the Environment}

In his prescient 1989 book, The End of Nature, the American environmental critic, Bill McKibben, argues that unless we reduce the amount of carbon dioxide in the atmosphere, nature as we have known it will be irreversibly damaged. "The momentum behind our impulse to control nature may be too strong to stop," he observes, "But the likelihood of defeat is not an excuse to avoid trying ... What is at stake is less the shape of our own lives than the very practical question of

the lives of all the other species and the creation they constitute." Climate 
change associated with toxic emissions, forest depletion, and other forms of environmental destruction have become a major international policy issue. Whether an international Climate Change Treaty can be agreed up at the December Copenhagen conference remains to be seen. A sustainable future, however, depends not only on the policies of international legislation and enforcement but on a fundamental shift in our use of natural resources and basic attitudes toward the natural environment from one of abuse and exploitation to respect and conservation. On a global scale, the degradation of the ecosystems on which all life depends threatens not only local environments but the very well-being and survival of humans, animals, plants, and cultures throughout the world. The future sustainability of the world's ecosystems will depend on contributions of scientists, policy makers, and also the active leadership of the world's religions, including Buddhism. In recognition of this fact, the Center for the Study of World Religions(CSWR) at Harvard sponsored eleven conferences between 1996 and 1998 on the world's religions and ecology that resulted in the publication of nine conference volumes the first of which was Buddhism and Ecology: The Interconnection of Dharma and Deeds(1997). In 2005 the CSWR joined with Dongguk University to co-sponsor a conference at Harvard on "Buddhism, Ecology, and Environmental Studies," and in 2006 the Center co-sponsored the conference, Ethics, Values, and the Environment, with the Harvard University Center for the Environment. Papers from the conference were published under the title, Ecology and the Environment: Perspectives from the Humanities(2008).

Buddhism and other world religions bring spiritual and ethical considerations to environmental and economic debates about climate 
change. The Forum on Religion and Ecology was founded on the principle that the moral imperative and value systems of religions are indispensable in mobilizing the sensibilities of people toward preserving the environment for future generations. Archbishop Desmond Tutu and James Leape, Director General of the World Wildlife Fund note that global warming is not just an ecological and financial dilemma but an ethical one that opens up fundamental questions about justice, fairness, responsibilities, and obligations. And at the Interfaith Summit on Climate Change in Uppsala, Sweden, in November, 2008, leaders from seven international religious bodies declared solidarity with scientists and political leaders in shouldering the responsibility of being conscious caretakers of planet Earth. One of the delegates observed that the world religions have an important role to play in re-visioning a sustainable future because they are the repositories of values and norms that guide human actions toward the natural world; that through cosmological narratives, symbols, rituals, ethical directive, and institutional structures, religions shape how we act toward the environment. Buddhism is a prime case in point.

The Aggañna Sutta, the myth of origins in the Pâli canon, describes the deleterious impact of human activity on the primordial natural landscape. Unlike the Garden of Eden story in the Hebrew Bible where human agency centers on the God-human relationship, the Buddhist story of first origins describes the negative impact of humans on the earth created by selfishness and greed. In the Buddhist mythological Eden, the earth flourishes naturally, but greedy desire leads to division and ownership of the land that in turn promotes violent conflict, destruction, and chaos. In short, in the Buddhist myth of first origins, human agency destroys the natural order of things. Though change is inherent in nature, 
Buddhists believe that natural processes are directly affected by human morality both negatively and positively.

In previous writings on Buddhism and ecology, I have highlighted four dimensions of the Buddhist worldview with potential ecological saliency: existential, moral, cosmological, and ontological. Existentially, Buddhists affirm that all sentient beings share the fundamental conditions of old age, suffering, and death. The existential realization of the universality of suffering lies at the core of the Buddha's teaching, and insight into the nature of suffering, its cause and its cessation constitute the capstone of the Buddha's enlightenment. Buddhist environmentalists postulate that mindful awareness of the universality of suffering leads to compassionate empathy for all life forms, and that from a concern for the total living environment, loving-kindness and compassion are extended beyond human beings and animals to include plants and the earth itself. The concepts of karma and sausāra fuse the existential sense of the shared common condition of all sentient life forms with a moral dimension. While evolutionary theory maps commonalities and differences among species on the basis of genetic traits, rebirth links them on moral grounds. Every form of sentient life participates in a karmic continuum, and although there is a karmic hierarchy, differences among individuals are relative not absolute.

Nirvāna, the Buddhist highest good, offers the promise that we can transform karmic lives into a state of spiritual liberation, a realization potentially available to all forms of life on the karmic continuum. That plants and trees or the land itself have a similar potential for spiritual liberation became an explicit teaching in Chinese and Japanese Buddhism. For T'ien-t'ai monks in eighth century China, the belief in a universal 
Buddha-nature blurred the distinction between sentient and nonsentient life-forms and logically led to the view that plants, trees, and the earth itself could achieve enlightenment. Kukai(774 835), the founder of the Japanese Shingon school and Dogen(1200 1253), the founder of the Soto Zen sect, described universal Buddha-nature in naturalistic terms, "If plants and trees were devoid of Buddhahood, waves would then be without humidity"(Kukai); “The sutras [i.e., the dharma] are the entire universe, mountains, and rivers and the great wide earth, plants and trees"(Dogen). Buddhist environmentalists cite Dogen's view as support for the preservation of species biodiversity. From an ecological perspective, the inclusion of animals and even plants in the Buddhist soteriological scheme ascribes inherent value to nonhuman life forms. Humans, however, have been the primary agents in creating the present ecological crisis and we will bear the major responsibility for solving it.

As reported by the United Nations Environment Programme, environmental activism inspired and motivated by religious groups, including those in Buddhist Asia, has become a global reality. Opposition to the commercial development of natural landscapes traditionally associated with Buddhist temples and monasteries has emerged in Korea and other Asian countries. At a 1995 conference at the Dae Won Sa Temple of Hawaii, the largest Korean Buddhist Temple in North America, Professor Jae-ryong Shim reported on the efforts of the Gwang Sa Temple to block the construction of an underground hydroduct tunnel behind the Jogye Mountain on the grounds that it was inimical to the mountain's sacred, geomantic configuration. Recently the Los Angeles Times carried a story about the unsuccessful struggle of the Chogye nun, Jiyul Sunim of Naewonsa, a monastery on Mt. Choenseong, to block the construction 
of a tunnel through the mountain that will link Seoul and Pusan, and her current activities to protect the Nakdong River as part of her Green Resonance Movement. The case I know best is in northern Thailand. In 1993, concerned Buddhist monks and laity joined with environmentalists to block the construction of a cable car to the top of Mount Suthep overlooking city of Chiang Mai. Wat Phrathat Doi Suthep, one of Thailand's most revered monasteries and a major pilgrimage site is located there. The cable car, endorsed by the Tourist Organization of Thailand, would accommodate the ever-increasing number of tourists who flock to Thailand's northern mountains. Long gone are the days when pilgrimage to Wat Phrathat was on foot, but the two lane road to the sanctuary construed by donated, manual labor under the inspired leadership of the charismatic monk, Khruba Siwichai, has itself, become part of the mountain's legendary history. A commercial company building a cable car to promote an increasingly invasive commercial degradation of Mount Suthep was another matter, however. Environmentalists, university professors. students, and ordinary citizens united in protest. A key element in its success was the role played by Buddhist monks, especially Phra Bodhirangsi, the assistant ecclesiastical governor of the province of Chiang Mai, one of the most highly respected abbots in the city. An abbreviated review of the defense of Mount Suthep in the face of the onslaught of commercial development and tourism is found in an editorial in the April 30, 1986, Bangkok Post which illustrates the deeply held reverence for the mountain:

The manager of the propose cable car project on Mount Suthep, Chiang Mai, states that he was 'not overlooking the sanctity of Wat Phrathat. 
He underestimates the northern people: The Soul of Lanna [northern Thailand] is still alive. Northerners perceive, at least in their subconscious, that Mount Suthep is like a symbolic stupa. Mount Suthep's dome-like shape is like an immense replica of the ancient Sanchi style stupa, a gift to Lanna by the Powers of Creation. Stupas are reliquaries of saints. More than that, they are a structural representation of the very essence of Buddhism. Plant and animal life are like Nature's frescoes, both beautifying and exemplifying the Law [dharma] not less than paintings in any man-made shrine. Although sometimes not being able to explain why rationally, the northern people want to preserve the Stupa Mount Suthep as it was given to them by Creation, as untouched as possible, as sacred.

Poverty, global health, terrorism, consumerism, the environment - are a few of the problems confronting the world's religions in this century. In addition to these difficult and troublesome social, economic, and political challenges, the development of a wide range of advanced technologies genetic, robotic, information, and nano--raise questions not only about human flourishing but our understanding of what it means to be human. The world's religions have an important contribution to make to these 21 st century challenges, most importantly a deepened, spiritual understanding of what it means to be fully human.

도널드 K 스웨러는 미국 하바드대학교 불교연구 객원교수이며, 세계종교 연구센터(Center for the Study of World Religions)의 소장이다. 주요 저서로 는 The Buddhist World of Southeast Asia(1995)가 있으며, 관심분야는 동남 아시아의 불교 및 불교와 생태학이다.

*이 글은 불교학연구원에서 주최한 <해외석학 초청강연회>(2009. 10. 22)에 서 발표된 것이다. 


\section{1세기의 도전들에 대한 불교적 대응방안}

도널드 K. 스웨러(하바드대)

번역 : 혜융(이정수) 외

오늘 '21세기의 도전들에 대한 불교적 대응방안'이라는 주제로 여러 분들께 말씀드릴 수 있도록 초청해주신 조계종 중앙승가대학교의 총 장 태원 스님과 불교학연구원장 미산 스님께 감사드립니다. 불교 단체 들이 '어떻게 21 세기에 이목을 그는 사회적 - 경제적 - 정치적 · 문화적 쟁점들에 관여해야 하는가라는 질문은 모든 세계 종교들이 직면한 도 전이기도 합니다. 지구촌의 도전들 가운데서 중요한 것에 포함되는 것 들은 빈곤, 더 공평한 자연자원과 부의 분배, 적절한 세계적 건강보험 제도와 광범위한 질병의 치료, 테러리즘과 대량살상 무기의 위협, 인간 에게 과학기술의 도전들이 의미하는 것, 소비주의와 탐욕의 경제, 그리 고 환경보존 등입니다.

오늘 저는 마지막의 두 가지 문제인 소비주의와 환경문제를, 과학기 술에 대한 논평을 간략하게 곁들여서 말씀드리고자 합니다. 저의 논평 들은 주로 테라바다 동남아시아 맥락, 특히 태국의 상황 하에서 불교 의 사회적 윤리에 대한 오랜 기간 동안 지속된 관심에서 형성된 저의 
연구에 근거한 것입니다. 저는 방콕(Bangkok)에 본부를 두고 있는 참 여불교국제네트워크( $\mathrm{INEB})$ 의 자문위원회의 일원이며, $\mathrm{INEB}$ 의 공동 창립자인 술락 시바락사(Sulak Sivaraksa)와 저명한 태국의 승려이자 정신적인 스승인 붓다다사 비구(Buddhadasa Bhikkhu)와 함께 긴밀하 게 일해 왔습니다. 저의 의견을 형성한 배경은 이와 같은 것입니다. 세계의 종교들은 반드시 이러한 21세기의 도전들을 설명하기 위해 서 경쟁이 아닌 협력을 통하여 작업해야만 합니다. 이러한 도전들에 대한 해결책은 단순히 정치가들, 경제학자들, 과학자들, 정책 입안자 들, 그리고 과학기술 전문가들뿐만 아니라, 인간의 번영이라는 생태학 에 있어서 인간의 조건과 성과에 관한 이해에 대해 공유되는 정신적 윤리적 견해들에 집중하는 이들에게도 의지해야 합니다. 공유되고, 보 편적인 선에 대한 자각에서의 협력은, 얼마나 좋은 의도를 가지고 있 는 가와는 상관없이 단순한 이기심에서 추구하는 것보다 반드시 우선 되어야 합니다.

\section{탐욕, 소비, 그리고 불교 경제학}

현시점의 세계적인 경제 위기는 미국과 다른 국가들에서 지불금, 지 원금, 보조금, 부채, 그리고 경기 부양책에 대한 논쟁들을 훨씬 넘어서 는 광범위한 토론을 불러 일으켰습니다. 사회 비평가들은 기업의 탐욕 을 격렬히 비난하고, 엄격한 규제를 요구하며, 그러한 위기에 잠재해 있던 거품들에 가혹한 평가를 내리고, '많을수록 좋다'는 소비 중심주 의자의 생활 방식에서 전환할 것을 외쳐댑니다. 오늘날, 수십 년간의 유례없는 성장 이후에, 우리는 더 많은 것이 반드시 좋은 것만은 아니 라는 것을 배웠습니다. 그것은 경제를 팽창시키는 것이 매우 비극적으 로 위험할 수 있으며, 실제로 성장이 우리를 더 부유하게 만든다고 할 때에도 그 막대한 부는 더 이상 우리를 행복하게 할 수 없습니다. 물론, 
이러한 통찰이 새로운 것은 아닙니다. 세계의 주요한 종교들과 철학적 전통들은 절제를 권장하고 제어되지 않은 소비를 비판합니다. 불교는, 그 시작에서부터, 고행적인 금욕과 방종한 부유함 사이에서 중도를 지 지했습니다.

불교도의 견해에서 근본적인 질문은 '경제 체제가 윤리적이고 정신 적인 계발에 이바지하는가'라는 것입니다. 경제 체제가 '세 가지 독(탐 욕- 분노·어리석음)'을 제도화하기보다 관용·자애·지혜의 덕성들 을 고취시킵니까? 불교는 가난함을 장려하지도 않고 부유함을 비난하 지도 않습니다. 오히려 부처님의 중도는 욕망들을 충족시키려는 우리 의 일상적인 몰입으로부터 해탈하는 것에 도움이 되는 이해와 통찰에 초점을 맞추고 있습니다. 태국에서 사회참여불교에 지대한 영향을 미 쳤던 저술들의 [저자인] 태국 승려 붓다다사 비구의 견해에서, 불교의 중도는 사물들의 자연적인 질서를 반영하는 것으로, 균형 잡힌 분배와 욕구보다는 필요에 기반을 둔 지속성의 하나입니다.

“자연은 우리가 실제로 필요한 것 이상으로 우리들 각각을 이용하 지 않을 것이다. 수년 동안 사람들은 자연의 방식을 유념하지 않았고, 가능한 한 많은 것을 차지하려는 서로간의 경쟁은 오늘날 우리가 함께 하는 문제들을 야기하고 있다. 우리가 필요한 것만을 취할 수 있다면, 이러한 문제들은 더 이상 존재하지 않을 것이다. 그렇다면 문제는 얼 마나 많이 필요하느냐는 것이다. 요즘은 어떤 것도 결코 충분하지 않 은 것으로 보인다. 불교의 속담에, '두 개의 황금 산이 있더라도 한 사 람의 욕망을 채우기에 충분하지 않다고 하였다. 요구되는 것은 필요한 것 이상으로 취하지 않을 것을 강조하고, 동시에 자연 법칙들과의 조 화를 이루는 접근이다. 그러면 사람들이 자비심으로 그들의 여분을 나 눌 것이기 때문이다. 자연의 최고 법칙은 우리들이 필요로 하는 것만 을 취하고, 사회의 이익을 위한 만큼을 축적하거나 생산하는 것이다." 
스리랑카에서 11,000 여 마을 이상의 개발 프로젝트를 수행해온 사르 보다야 슈라마다나 운동의 창시자인 아리야라트네(A. T. Ariyaratna) 에게 있어서, 불교의 중도는 그가 명명하는 '가난 없는 사회'로 변환됩 니다. 슈라마다나는 실질적인 땅 위의 모든 이들을 위한 풍부함이라는 목표를 거부합니다. 풍부함은 모두가 얻을 수 없습니다. 세상은 절대로 충분한 자원을 가지고 있지 않습니다. 풍부한 사회를 건설하기 위한 사회적 - 환경적 - 도덕적 - 문화적인 비용은 너무 막대하며, 부자와 가 난한 이들 간의 차이를 심화시킵니다. 사르보다야의 마을 개발 프로젝 트의 경우, 가난 없는 사회는 열 가지 기본적인 요건에 부합되는 선에 서 정의됩니다. [그것은] 깨끗하고 매력적인 육체적·심리적 환경, 깨끗 하고 적당한 물 공급, 균형 잡힌 식품에 대한 요건, 적절한 의복에 관한 요건, 단순하지만 적절한 주택, 기본적인 의료보험, 기본적인 통신 시 설, 최소 에너지에 관한 요건, 종합적인 교육, 문화적이고 정신적인 욕 구들의 충족 등입니다. 수입과 고용은 가난 없는 경제의 일부분일 뿐 입니다. 마을 경제에서 생산의 목적은 이익을 축적하는 것이 아니며, 오히려 공동체의 옥구들을 충족시키기 위한 것이고, 그렇게 함으로써 공동체의 모든 구성원들을 그러한 과정으로 참여시키는 것이며, 이는 일자리, 교육, 공통의 이익을 위한 협력과 공통된 문제들의 해결을 위 한 기회들인 것입니다.

현대의 불교 경제 윤리는 소비주의를 문화적이고 종교적인 가치들 을 빙자해서 상품화한 것으로 비판합니다. 태국의 불교 사회 활동가이 며 참여불교국제네크워크(INEB)를 비롯한 수많은 불교 NGO단체들 의 창립자인 술락 시바락사(Sulak Sivaraksa)는 소비주의를 새로운 악 마적인 종교로 간주하고 있으며, 태국의 저명한 환경운동가인 프라 파 이산 비사로(Phra Phaisan Visalo) 스님은 이렇게 한탄합니다. "종교 적인 신념과 소비주의 차이점은 오늘날 눈에 띄게 모호해지고 있다. 
오늘날, 종교적인 신념은 참배를 위해 상서로운 사물들을 구입하는 것 을 의미하는 정도로 변질되었다. 신심은 더 이상 그가 어떻게 종교를 삶에 적용하고, 어떻게 인생을 사는가에 의해 평가되지 않으며, 오직 얼마나 많이 성스러운 물건들을 가지고 있는 가로 평가된다."

비록 현대에 사회적으로 참여하는 불교도들이 소비주의를 새로운 세계 종교로 몰아세우지만, 불교의 중도 윤리는 부(富)의 축적을 거부 하지는 않습니다. 그러나 그것의 획득과 사용에 관한 지침들을 세우고 있습니다. 정직하게 얻은 부(富)는 칭찬받을 만한 것이지만, 정직하고 합법적으로 얻었을 때라도 인색함(자신의 이익과 복지와 안녕 등을 위 해 가진 것을 나누지 않으려하는 것)과 같은 부(富)에 대한 집착은 비 난받아야 하는 것입니다. 부(富)를 획득함이, 만약 동시에 공동체나 사 회의 복지를 위한 것이라면, 이는 인정받을 만한 것입니다.

가장 칭송받을 만한 도덕적 가치 중의 하나는 특히 가난한 사람들에 게 아낌없이 주는 자발적인 행위입니다. 부(富)에 대한 세 가지 기본적 인 태도는 아낌없이 주는 것의 가치에 대한 근간을 이룹니다. 첫째로, 보시는 갈애와 축적에 대한 불교도의 비판을 드러냅니다. 불교에서는 무집착의 자세를 닦아 나가고 표현하는 것에 대해 가장 많이 강조하고 있습니다. 귀중한 선물이 이기적인 이유로 주어진다면 주는 이에게 이 득이 없고 심지어 피해까지도 줄 수 있지만, 이기심 없이 주는 작은 선 물이 더욱 더 칭송받을 수 있습니다. 둘째로, 보시는 부(富)를 향한 태 도와 그를 사용하는 방법보다 부(富)를 소유한 양과 그것의 나눔이 도 덕적으로 덜 중요하다는 것을 분명히 합니다. 셋째로, 도덕적인 원칙에 서 보시가 물질적인 번영이라는 일시적인 부(富)의 가치일 뿐임을 분 명히 합니다. 적당한 방법으로 사용되는 부(富)는 선이며, 적절하게 사 용된 부(富)는 개인과 공동체 모두를 이롭게 합니다.

불교도의 경제적인 관점에서 일 혹은 노동을 바른 생계수단이라는 
더 넓은 틀에서 살펴보아야 합니다. 즉, 인간의 능력을 계발하는 기회 로, 공동 작업에서 다른 사람들과 함께하는 것으로 자기중심주의를 극 복하기 위해서, 그리고 만족스러운 삶을 위해 필요한 상품과 서비스를 생산하기 위해서입니다. 『작은 것이 아름답다: 인간 존중의 경제학 (Small Is Beautiful: Economics As If People Mattered)』의 저자 슈 마허(E. F. Schumacher)는 소비가 경제 활동의 목적이 되어야 한다고 생각하며, 생산적인 노력의 최적화된 양식에 의한 소비의 최적화된 양 식에 인간 만족의 최대치를 관련짓는 현대 서구의 경제학자들을 비판 합니다. 그러나 불교 경제학의 입장에서, 이런 경제학에 대한 이해는 합리적이지도 도덕적이지도 않습니다. $\mathrm{GNP}$ 로 부(富)를 측정하고 삶 의 기준을 해마다의 소비량으로 측정하는 경제학적인 기준과는 상반 되게, 불교 경제학은 소비를 인간 복지를 위한 수단으로서 바라봅니다. 불교 경제학은 인간 번영의 본질은 욕구들의 증식에 있는 것이 아니라 인간 특성의 계발, 혹은 베트남 승려인 틱낫한(Thich Nhat Hanh)의 말에서와 같이, 우리의 가장 깊은 자아의 표현에 있다고 주장합니다. 그러므로 노동은 인간의 특성과 존엄성을 장려하는 데 그 목적을 두어 야 합니다.

\section{불교, 생태학, 그리고 환경}

미국의 환경 비평가인 빌 맥키벤(Bill Mckibben)은 그의 예지적인 1989년도의 저서『자연의 종말(The end of nature)』에서 우리가 대기 권의 이산화탄소 양을 줄이지 않는다면, 우리가 알고 있는 것과 같은 자연은 돌이킬 수 없는 손상을 받을 것임을 논합니다. “자연을 통제하 려는 우리의 충동 뒤에 있는 추진력은 너무 강해서 멈출 수 없을지도 모른다,” 그가 말하길, “그러나 실패할지 모른다고 해서 시도도 하지 않을 이유가 되는 것은 아니다. $\cdots$ 모든 다른 종들의 생명들과 그들이 
이뤄낸 산물들에 관한 매우 실제적인 질문보다 우리 자신의 생명들의 형태가 보다 덜한 위험에 처해있는 것이다." 독극물 배출, 숲의 황폐화, 그리고 다른 형태의 환경 파괴들과 연관된 기후 변화는 국제 정책의 주요한 이슈가 되고 있습니다. 국제기후변화조약(An International Climate Change Treaty)이 코펜하겐(Copenhagen) 회의에서 합의를 이뤄낼 수 있을지 어떨지는 계속 주시해야 할 것으로 남아있습니다. 그러나 지속적인 미래는 국제적인 법률 제정과 시행에 의한 정책들뿐 만 아니라, 우리가 자연 자원을 이용하는 것과 자연 환경에 대한 기본 적인 태도들이 남용과 개척에서 존경과 보존으로 근본적으로 변화하 는 데 달려있습니다. 전 지구적인 차원에서 모든 생명들이 의존하는 생태시스템의 퇴화는 지역적인 환경들뿐만 아니라 인간, 동물, 식물, 그리고 세계의 문화들의 복지와 생존도 위협합니다. 미래 세계 생태시 스템의 지속성은 과학자들, 정책 입안자들, 그리고 또한 불교를 포함한 세계 종교들의 활발한 리더십의 공헌에 의존할 것입니다. 이러한 사실 에 대한 인식에서, 하버드의 세계종교연구센터에서는 세계의 종교들 과 생태학에 대해 1996 년부터 1998 년까지 11 번의 회의들을 주최하였 고, 그 결과로 『불교와 생태학: 다르마와 행위들의 상호 관련성 (Buddhism and Ecology: The Interconnection of Dharma and Deeds)』(1997)을 첫 번째로 하는 9 권의 회의 간행물이 출판되었습니 다. 2005년에 세계종교연구센터에서는 동국대학교와 함께 하버드에서 "불교, 생태학, 그리고 환경 연구(Buddhism, Ecology, and Environ -mental Studies)"라는 회의를 공동주최하였으며, 2006년에는 하버드 대학의 환경 연구센터(Center for the Environment)와 함께 "윤리, 가 치관, 그리고 환경(Ethics, Values, and the Environment)"이라는 주제 의 회의를 공동주최하였습니다. 이 회의의 논문들은 『생태학과 환경 : 인문학으로부터의 견해들(Ecology and the Environment : Per- 
spectives from the Humanities)』(2008)이라는 제목으로 출판되었습 니다.

불교와 다른 세계 종교들은 기후 변화에 대한 환경적이고 경제적인 논쟁들에 영적이고 윤리적인 의견들을 제시합니다. 종교와 생태학에 관한 공개토론은 미래 세대를 위해 환경을 보존하도록 사람들의 공감 을 이끌어내는 데 종교들의 도덕적 강령과 가치 체계들이 불가결한 것 이라는 원칙에서 이루어졌습니다. 추기경 데스몬드 투투(Desmond Tutu)와 세계 야생동물 기금(World Wildlife Fund)의 총장인 제임스 리프(James Leape)는 지구 온난화는 생태학적이고 재정적인 딜레마 일 뿐만 아니라 정의, 공정함, 책임감, 의무감에 관한 근본적인 질문들 을 펼쳐내는 윤리적인 딜레마이기도 하다는 것을 지적합니다. 그리고 2008년 11월 스웨덴 웁살라(Uppsala)에서 기후 변화에 관해 종파를 초 월한 정상 회담에서, 7 개의 세계적인 종교 단체의 리더들이 과학자들 과 정치 지도자들과 함께 행성 지구의 의식 있는 관리인이 되어야 한 다는 책임감에 어깨를 나란히 하는 공동 연대를 선언했습니다. 대표들 가운데 한 분은 세계의 종교들이 자연 세계를 향한 인간의 행위들을 안내하는 가치와 규범의 보고이기에 지속적인 미래를 수정하는 데에 중요한 역할을 한다고 말씀하셨습니다. 그러한 우주적인 설화, 상징, 의식, 윤리적 지시와 제도적인 구조를 통해서 종교들은 어떻게 우리가 환경을 향해서 행동할 것인지를 제시합니다. 불교는 그러한 점에서 가 장 주요한 사례들을 보여줍니다.

빨리 경전에서 세계의 근원에 관한 이야기인 『아간냐경(aggañña sutta ; 小緣經, DN., no.27 ; 長阿含., no.5)』에서는 원시적인 자연 풍경 에서 인간 활동의 해로운 영향을 서술합니다. 신과 인간의 관계에서 인간 활동 영역이 중심되는 히브리 성경 속에 에덴의 정원 이야기와는 다르게, 최초의 기원에 관한 불교의 이야기는 이기심과 탐욕에 의해 
창조된 지구에서 인간들의 부정적인 영향을 서술합니다. 불교에서 신 화적인 에덴은 자연적으로 번성하는 곳이지만, 탐욕스러운 욕망이 폭 력적인 분쟁과 파멸과 혼돈을 일으키는 토지의 분배와 소유권을 추구 하게 합니다. 즉, 불교도의 최초 기원에 관한 설화에서 인간의 활동 영 역이 사물들의 자연적인 질서를 파괴하는 겁니다. 변화가 본래부터 자 연 안에 존재하는 것이기는 하지만, 불교도들은 자연적인 과정들은 인 간의 부정적이거나 긍정적인 도덕성 모두에 의해 직접적으로 영향 받 는 것이라고 믿습니다.

불교와 생태학에 대한 지금까지의 내용에서 저는 잠재하는 생태학 적 특징과 함께 불교도의 세계관에 대해 네 가지 범위(경험적, 도덕적, 우주론적, 그리고 존재론적 측면)들을 강조했습니다. 경험적으로, 불교 도들은 모든 중생들은 늙음 - 괴로움 - 죽음이라는 근본적인 조건들을 공유한다는 것을 확신합니다. 괴로움의 보편성에 관한 경험적인 깨달 음은 부처님의 가르침에서 핵심에 놓이는 것이고, 괴로움의 성품과 그 것의 원인과 그것의 소멸에 대한 통찰은 부처님 깨달음의 정점을 이룹 니다. 불교 환경운동가들은 괴로움의 보편성에 대해 마음 챙기고 알아 차리는 것[正念正知]이 모든 생명체들에 대해 연민하는 공감으로 이끌 며, 그것은 또한 전체적인 생명 환경에 대한 배려로부터 나오는 것으 로, 자비가 인간과 동물들을 넘어서서 식물들과 지구 자체까지 포함하 는 영역으로 확장되게 합니다. 업과 윤회의 개념들은 모든 지각 있는 생명체들의 공유된 공통 조건이라는 경험적인 의미와 도덕적인 차원 을 융합시킵니다. 진화론이 유전적인 특성들의 토대 위에서 종들의 공 통점과 차이점을 재고 있는 동안 윤회는 그것들을 도덕적인 바탕들에 연관시킵니다. 모든 형태의 중생들은 업의 흐름에 참여하고 있으며, 비 록 업의 차별이 있을지라도 개개의 차이들은 상대적인 것이지 절대적 인 것은 아닙니다. 
불교도의 궁극적인 선인 열반은 우리가 업을 정신적인 해탈의 상태 로 전환할 수 있으며, 그러한 깨달음은 잠재적으로 업의 흐름에 처한 모든 생명체들이 가능한 것이라는 약속을 제공합니다. 식물들과 나무 들 혹은 대지 그 자체도 정신적인 해탈과 유사한 가능성을 가진다는 것이 중국과 일본 불교에서는 분명한 가르침이 되었습니다. 8 세기 중 국의 승려인 티엔 타이(天台)에게 우주적인 불성에 대한 믿음은 유정 (有情)과 무정(無情)의 구별을 흐리게 했으며, 이치적으로 식물들, 나 무들, 그리고 지구 자체도 깨달음을 성취할 수 있다는 견해로 이끌었 습니다. 일본 진언종(眞言宗)의 개창자인 쿠카이(空海, 774 835)와 조 동종(曹洞宗)의 창시자인 도겐(道元, 1200 1253)은 사실적인 용어로 써 우주적인 불성을 표현했습니다. "식물들과 나무들에 불성이 없다면, 파도는 습기가 없게 될 것이다.(쿠카이)"; “경전들 (즉, 다르마)이 전 체 우주이고, 산들이고, 강들이며, 대지이고, 식물들이며, 나무들이다. (도겐)” 불교 환경운동가들은 생물의 다양한 종들의 보존에 대한 근거 로서 도겐의 견해를 인용합니다. 생태학적인 견해에서, 불교도의 구원 론적인 체계 안에 동물들과 식물들까지 포함되는 것은 인간이 아닌 생 명체에 본래 갖추어진 가치에 기인합니다. 그러나 인간들은 현재의 생 태학적인 위험들을 만드는 데에 있어 가장 주요한 행위자였으며, 우리 는 그것을 해결하는 데 주요한 책임을 져야 할 것입니다.

$\mathrm{UN}$ 환경 프로그램의 보고에 의하면, 그와 같은 아시아의 불교도들 을 포함한 종교적인 단체들에 의해 고취되고 자극받은 환경운동은 세 계적인 현실이 되고 있습니다. 전통적으로 불교 사찰들과 관련된 자연 풍경들의 상업적인 개발에 대한 저항이 한국과 다른 아시아 국가들에 서 나타나고 있습니다. 북미에서 가장 큰 한국불교 사찰인 하와이 대 원사의 1995 년 회의에서, 심재룡 교수가 조계산의 신비한 지리적 형상 들을 해치는 지하터널 공사를 막으려는 송광사의 노력을 보고했었습 
니다. 최근에 로스엔젤레스 타임스(Los Angeles Times)는 천성산 내 원사의 비구니 지율 스님이 산을 관통해 서울과 부산을 잇게 될 터널 공사를 막으려던 분투가 성공적이지 못했던 것과 '초록의 공명' 운동의 일환으로 낙동강 보호를 위한 현재의 활동들을 전했습니다. 제가 아는 최고의 사례는 태국 북부에 있습니다. 1993년에 치앙마이시를 내려다 보는 수텝산(Mt. Suthep) 정상에서의 케이블카 공사에 대해 우려했던 불교 승려들과 재가 신도들이 환경 운동가들과 함께 공사를 막아냈던 것입니다. 프라탓 도이 수텝(Wat. Phrathat Doi Suthep) 사원은 태국 에서 가장 많이 참배하는 사찰들 중의 하나이며, 주요한 순례 장소가 그곳에 위치하고 있었습니다. 태국의 관광청에 허가를 받았던 그 케이 블카는 태국 북부의 산으로 끊임없이 몰려오는 관광객들을 수용하기 위한 것이었습니다. 오래 전에 프라탓 사원으로 가는 순례가 도보로 행해졌을 때부터, 카리스마적인 크루바 시위차이(Khruba Siwichai) 스님의 영감을 주는 리더십 아래 수작업으로 그 성지에 2차선의 도로 가 [놓인 것은] 그 자체로 수텝산의 전설적인 역사의 일부가 되었습니 다. 그러나 상업적인 기업이 수텝산에 대한 공격적이고 상업적인 타락 을 촉진하기 위해 케이블카를 건설하는 것은 또 다른 것이었습니다. 환경운동가들, 대학 교수들, 학생들, 그리고 일반 시민들이 시위에 모 였습니다. 그러한 성공에서 핵심적인 요소는 불교 승려들, 특히 치앙마 이 교구의 교구 총재 비서이자 시에서 가장 존경받는 대수도원장들 가 운데 한 분이신 프라 보디랑시(Phra Bodhirangsi) 스님에 의해 수행된 역할이었습니다. 상업적인 개발과 관광의 공격에 직면한 수텝산의 수 호에 관해 정리한, 1986년 3월 30일자 방콕 포스트(Bangkok Post)의 사설에서 그 산에 대한 깊은 경외심을 보이는 평론을 볼 수 있습니다.

치앙마이시 수텝산의 케이블카 공사 사업 계획의 감독관은 '프라탓 사 
원의 신성함은 보지 않았다'고 말한다. 그는 북부의 사람들을 얕보고 있다 : 그러나 라나(Lanna : 태국 북부의 명칭) 정신은 여전히 살아 있다. 태국 북부의 사람들은 적어도 그들의 잠재의식에서라도, 수텝산이 상징 적인 불탑과 같다는 것을 알고 있다. 수텝산의 둥근 지붕과 같은 모습은 고대 산치(Sanchi) 양식 불탑의 거대한 모사품과 같으며, 라나는 창조력 의 힘에 의한 선물이다. 불탑들은 성인들의 사리를 모신 곳이다. 그 이상 으로 그것들은 불교의 본질에 대한 구조적인 표현이기도 하다. 식물과 동물의 생명들은 자연의 그림과 같다. 이들은 모두 현상계(the Law; DHARMA)를 아름답게 하고 실증하는 데 있어서 그 어떤 인간에 의한 성지에서의 그림들보다 덜하지 않은 것이다. 비록 때때로 왜 그러한지 합리적으로 설명할 수는 없을 지라도, 북부의 사람들은 수텝산의 불탑을 창조에 의해 그들에게 주어진 대로, 가능한 한 손대지 않은 채로, 성스러 운 채로, 보존하기를 원한다.

가난, 지구의 건강, 테러리즘, 소비주의, 환경-이러한 것들은 이 시 대의 세계 종교들이 직면하는 여러 가지 문제들입니다. 이러한 어렵고 까다로운 사회적, 경제적, 정치적인 도전들에 더하여, 광대한 범위의 진보된 과학 기술들-유전공학, 로봇공학, 정보통신, 나노기술 등의 발 전은 인간의 번영뿐만 아니라 그것이 인간에게 어떠한 의미가 있는지 에 대한 우리의 이해에 관해서 문제를 제기합니다. 세계의 종교들은 이러한 21 세기의 도전들에 대해서 '그것들이 온전히 인간에게 어떠한 의미가 있는가라는 가장 중요한 심도 있고 영적인 이해를 구성하는 데 중요한 기여를 해야 합니다. 